\title{
THE EVOLUTION OF BIOCHEMICAL OXIDATION OF AMMONIA IONS IN SMALL RIVERS WATER
}

\author{
Elena Mosanu ${ }^{1}$, P. Spataru' ${ }^{1}$ T. Lupascu*2, Maria Sandu ${ }^{1}$, Tatiana Goreacioc ${ }^{1}$, A. Tarita $^{1}$ \\ ${ }^{1}$ Institute of Ecology and Geography, Academy of Science of Moldova \\ ieg@asm.md; tel/fax (373 22) 211134 \\ ${ }^{2}$ Institute of Chemistry, Academy of Science of Moldova \\ *ichem@asm.md; tel/fax (373 22) 725490
}

\begin{abstract}
Nitrification is the oxidation of ammonia to nitrate, via nitrite and it occupies a central position within the global nitrogen cycle. Nitrifying bacteria are the organisms capable of converting the most reduced form of nitrogen, ammonia, to the most oxidised form, nitrate, but their activity is influenced by pollution level. Starting with the assumption that pollution of small internal water courses in the Republic of Moldova remained severe (phenols, detergents and copper regularly exceed the MACs) the work presented in the paper discusses the evolution of ammonia ions nitrification in the water of river Prut tributaries and its correlation with the content of pollutants in water: surface-active substances, $\mathrm{Cu}, \mathrm{BOD}_{5}, \mathrm{COD}$ and other compounds.
\end{abstract}

Keywords: biochemical oxidation, ammonia ions, nitrification, small rivers.

\section{Introduction}

Ammonia is produced by human activity. It occurs naturally from the breakdown of nitrogenous organic compounds in water, soil and the breakdown of biota, being an important source of nitrogen which is needed by plants and animals.

The presence of ammonium ions in natural waters is associated with pollution caused by livestock, intensive agriculture, and liberation of domestic sewage in courses of superficial waters. A statistically significant increase in ammonium concentration was detected in pond water exposed to artificial radiation resembling sunlight in the UV range of the highest absorbance after $5 \mathrm{~h}$ of irradiation. In sea and river water a corresponding increase $(<0.5 \mu \mathrm{M})$ was recorded after an exposure time of 25 hours [1]. Trace amounts of ammonia $\left(\mathrm{NH}_{3}\right)$ in unpolluted water are present from the reduction of atmospheric nitrogen by aquatic microorganisms. Ammonia is at equilibrium with ammonium ion $\left(\mathrm{NH}_{4}^{+}\right)$and the equilibrium reaction between ammonia and ammonium ion is $\mathrm{pH}$ dependent.

$$
\mathrm{NH}_{3}(a q)+\mathrm{H}^{+}(a q) \rightleftharpoons \mathrm{NH}_{4}+(a q)+\mathrm{OH}^{-}(a q)
$$

So Thus, total ammonia is the sum of the two forms. Natural unpolluted waters may contain 0 to $3 \mathrm{mg} / \mathrm{l}$. Higher concentrations correspond to pollution and can be toxic to aquatic organisms. Sources of ammonia may be industrial discharges, particularly from the pulp and paper industry, fertilizer runoff, sewage releases into natural waters, and industrial releases.

Ammonia and ammonium salts are also found in small quantities in rainwater (ammonium chloride, sulfate and bicarbonate).

The plants (usually through their roots) consume ammonia taken up directly. Most of the ammonia is converted as a result of biochemical oxidation from a reduced to a more oxidized state, nitrate, by the Nitrifying bacteria. This is accomplished in two steps:

- Bacteria of the genus Nitrosomonas oxidize $\mathrm{NH}_{4}^{+} / \mathrm{NH}_{2}$ to nitrites $\left(\mathrm{NO}_{2}^{-}\right)$.

$$
\mathrm{NH}_{4}^{+}+\frac{3}{2} \mathrm{O}_{2} \leftrightarrow \mathrm{NO}_{2}^{-}+2 \mathrm{H}^{+}+\mathrm{H}_{2} \mathrm{O}
$$

- Bacteria of the genus Nitrobacter oxidize nitrites to nitrates $\left(\mathrm{NO}_{3}^{-}\right)$.

$$
\mathrm{NO}_{2}^{-}+\frac{1}{2} \mathrm{O}_{2} \leftrightarrow \mathrm{NO}_{3}^{-}
$$

The oxidation of ammonia to nitrate by microorganisms is a key process in the nitrogen cycle, resulting in nitrogen loss from ecosystems, eutrophication of surface and ground waters. In aquatic ecosystems nitrifies compete with primary producers for ammonia and in all ecosystems nitrification results in the generation of reactive gases, in particular nitrous oxide, involved in the destruction of stratospheric ozone and global warming.

Effluents containing nitrogenous compounds must be treated in order to reduce the release of ammonium- $\mathrm{N}$ into natural waters, because this causes oxygen demand, is toxic to aquatic life, leads to eutrophication, modifying the biota and creating an ecological imbalance. 
The First Step of the process $\left(\mathrm{NH}_{4}^{+} \rightarrow \mathrm{NO}_{2}^{-}, 66 \mathrm{kcal}\right.$ of energy are liberated per gram atom of ammonia oxidized) involved microorganisms called the ammonia oxidizers. The biochemical nitrite Oxidation $\left(\mathrm{NO}_{2}^{-}+1 / 2 \mathrm{O}_{2} \rightarrow\right.$ $\mathrm{NO}_{3}^{-}, 18 \mathrm{kcal}$ of energy is liberated per gram atom of nitrite oxidized) is the second step. Nitrate is the final product after completion of the biochemical oxidation. Nitrifying bacteria work either at full capacity or drift into a resting phase. Some substances will influence bacteria activity, such as phenol, surface-active compounds, heavy metals and others [2-8].

The nitrification process can have a direct impact on water quality. The end result of nitrification, nitrate $\left(\mathrm{NO}_{3}^{-}\right)$, is a form of nitrogen that is highly mobile and easily moves with water. When rainfall is heavy, nitrates can move downward in the soil and then in underground waters.

Start with the assumption that pollution of small internal water courses in the Republic of Moldova remained severe, recorded concentrations of ammonium, nitrite and other pollutants ( $\mathrm{BOD}_{5}$, oil products, phenols, and detergents) exceeded the maximum admissible concentration (MAC), the evolution of biochemical oxidation of ammonia ions in small rivers water was evaluated in this work.

To surface waters loads of pollution contributes the runoff from residential and industrial areas, domestic wastewater discharges from non-sewered population. The animal waste is not anymore concentrated in a limited number of sites; it is spread everywhere, on both private and public lands, threatening the drinking water sources and the surface waters. This major pollution source became more diffuse and less manageable. Another source of surface waters pollution is the non-observance of protection strips along the water courses. Within the settlements, these are transformed into domestic waste dumps.

\section{Materials and Methods}

It was used aA combination of laboratory and field studies was used to elucidate the factors controlling the growth, activity and survival of nitrifies in natural waters.

Nitrification capacity of small rivers water was investigated by means of laboratory modelling with employment of natural waters [9]. Analytical settlement of the problem was realized by controlling $\mathrm{NH}_{4}^{+}, \mathrm{NO}_{2}^{-}, \mathrm{NO}_{3}^{-}, \mathrm{O}_{2}$ and $\mathrm{pH}$.

In small rivers water, were determined the concentrations of macro-, nitrogen and organic compounds. Samples (3 $000 \mathrm{ml}$ ) of different aquatic environments were enriched with $\left(\mathrm{NH}_{4}\right)_{2} \mathrm{SO}_{4}$ to concentrations of $2.0-\mathbf{6 , 0} \mathrm{mg} / \mathrm{dm}^{3}$ and incubated on natural conditions at $20-22^{\circ} \mathrm{C}$. The content of $\mathrm{NH}_{4}^{+}, \mathrm{NO}_{2}^{-}$and $\mathrm{NO}_{3}^{-}$, and the $\mathrm{pH}$ were determined after the liquid was filtrated. This replacement procedure was repeated every 2-5 days.

Ammonia ions were determined by using the Nessler reactive [10]. Nitrite was estimated by the procedure with the Griess reagent, and the reduction method with the $\mathrm{Zn}-\mathrm{MnSO}_{4}$ mixture [11] was used to measure nitrate [12] and other compounds [13-16].

\section{Results and discursions}

The nitrification process can have a direct impact on water quality. The end result of nitrification, nitrate $\left(\mathrm{NO}_{3}^{-}\right)$, is a form of nitrogen that is highly mobile and easily moves with water. When rainfall is heavy, nitrates can move downward in the soil.

The river network in the Republic of Moldova is the final receptor of most runoff and wastewater, either household or industrial, as in any other country; the treatment level of wastewaters is insufficient and about $1 / 3$ of pollutants, including ammonia compounds, pesticides, detergents, some heavy metals still persist after treatment, being discharged into natural waters. The concentrations of ammonium, nitrites, phenols, detergents and copper regularly exceed the MACs. For example, ammonium concentrations were found of $17,0 \mathrm{mg} / \mathrm{dm}^{3}$ as $\mathrm{N}(43,6 \mathrm{MAC})$ up to $46,5 \mathrm{mg} / \mathrm{dm}^{3}$ as N (119 MAC) in the Bic river, downstream Chisinau (wastewater treatment station, WWTS), maintaining their high values up to the confluence with the Nistru river [17].

Out by experimental obtained results it was established that $\mathrm{NH}_{4}^{+} \rightarrow \mathrm{NO}_{2}^{-}$process in modeling of small rivers Ciuhur, Larga, Draghiste, Lopatnic, Calanjir, Racovat, Vilia, Bogda, Camenca water it takes place in the same way as river Nistru water and lasts 6-10 days, whereas in river Racovat water, only $40-77 \%$ of ammonium ions are oxidizes. Even after 15-20 days, 7-20\% of $\mathrm{NH}_{4}^{+}$remained in solutions. $\mathrm{NH}_{4}{ }^{+} \rightarrow \mathrm{NO}_{2}{ }^{-}$transformation in model with Vilia, Lopatnic (Lopatnic), Racovat (Grajdiesti) water take place in 15 days. In rivers Draghiste (Burlanesti), Bogda, Garla Mica, Bac, Racovat (Hadarauti), Raut (downstream Balti, Floresti, Orhei) and Cainari, the process lasts about 20-21 days, but in the case of r. Racovat (Clocusna), Lopatnic (Gremencauti), Draghiste (Bulboaca), Larga samples - 25 and more days (fig. 1, a-f). Process takes place for 21-25 days in the waters of r. Cainar (Gura Cainari), Ichel (Ratus), Isnovat (Ialoveni) and Camenca (Gura Camenca). 

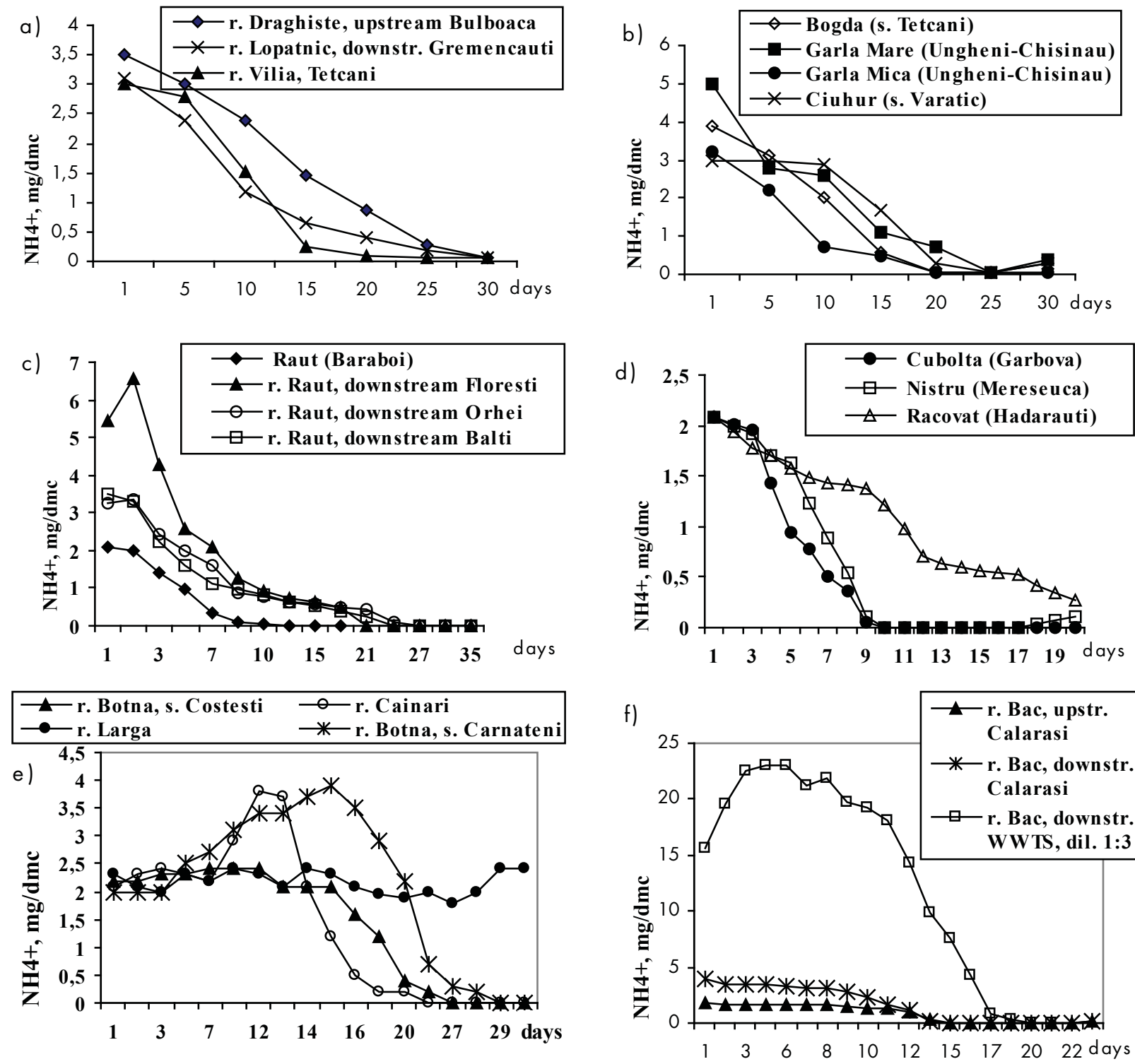

Figure 1. Evolution of $\mathrm{NH}^{+} \rightarrow \mathrm{NO}_{2}^{-}$process in small rivers water.

The second stage of nitrification $\left(\mathrm{NO}_{2}^{-} \rightarrow \mathrm{NO}_{3}^{-}\right.$) lasts 15 days in Garla Mica, Lopatnic (Lopatnic), Racovaț (Grajdiesti) rivers water; in r. Draghiste, Lopatnic (Gremencauti), r. Vilia (Cotiugeni) and Bogda - 25 days; r. Racovat (Clocusna), r. Draghiste (Burlanesti), r. Vilia (Tetcani) and r. Ciuhur (Varatic) the transformation $\mathrm{NO}_{2}^{-} \rightarrow \mathrm{NO}_{3}^{-}$was developed during 30 and more days. The time of nitrification correlates with the content of pollutants in water: surfaceactive substances, $\mathrm{Cu}, \mathrm{BOD}_{5}, \mathrm{COD}$ and other compounds.

a)

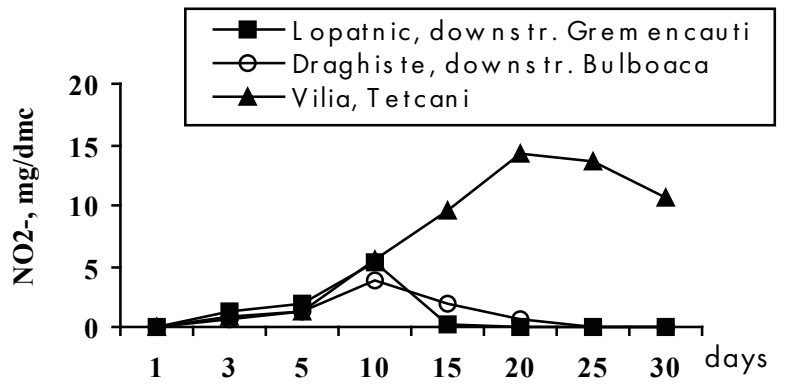

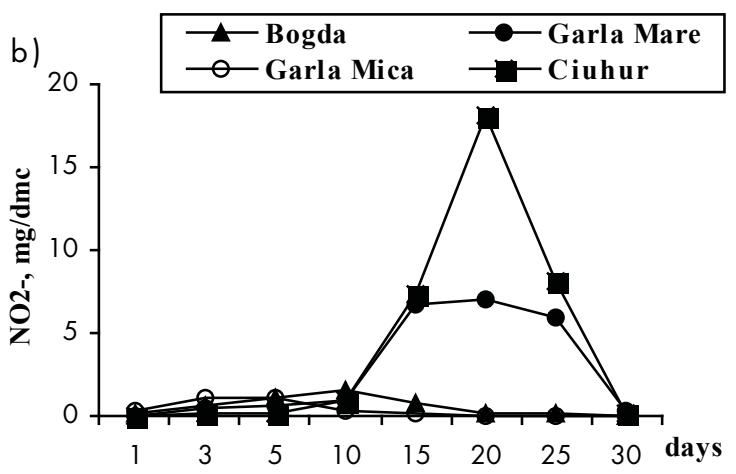



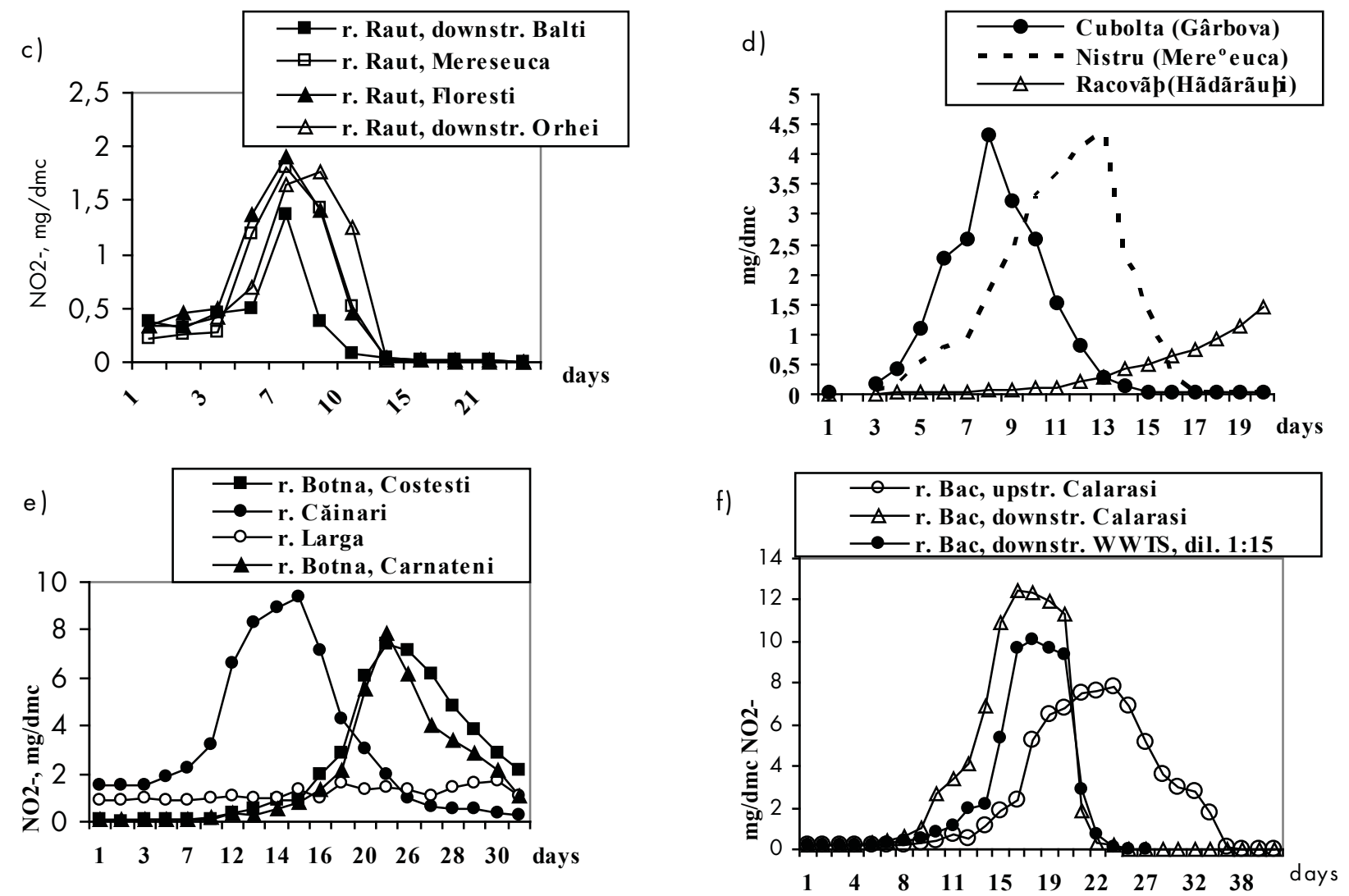

Figure 2. Evolution of the second stage of nitrification $\left(\mathrm{NO}_{2}^{-} \rightarrow \mathrm{NO}_{3}^{-}\right)$in rivers water.

The rate of ammonia oxidation exceeded the similar of nitrite process. Differences in oxidation rates can be attributed to ammonia-oxidizing bacteria out competing nitrite-oxidizing bacteria due to a number of factors, including free ammonia inhibition, dissolved oxygen concentration, heavy metals, organic matter, temperature and $\mathrm{pH}$ [18-20].

The study of nitrification in natural waters with high suspended-solid (SS) content indicated that the presence of SS could accelerate the nitrification process. The nitrification rate would increase non-linearly with the increase of suspended-solid content [21].

High suspended-solid content has useful implications for nitrogen removal from river systems in the Republic of Moldova: rivers Raut, Lopatnic, Cubolta, Cainari, Bac.

The time passing on ammonia ions oxidation is conditioned in natural small rivers water by organic and inorganic pollutants content, which influenced the activity of Nitrifying microorganisms, and correlated (fig. 2) with biological (BOD) and chemical oxygen demand (COD-Mn, COD-Cr).

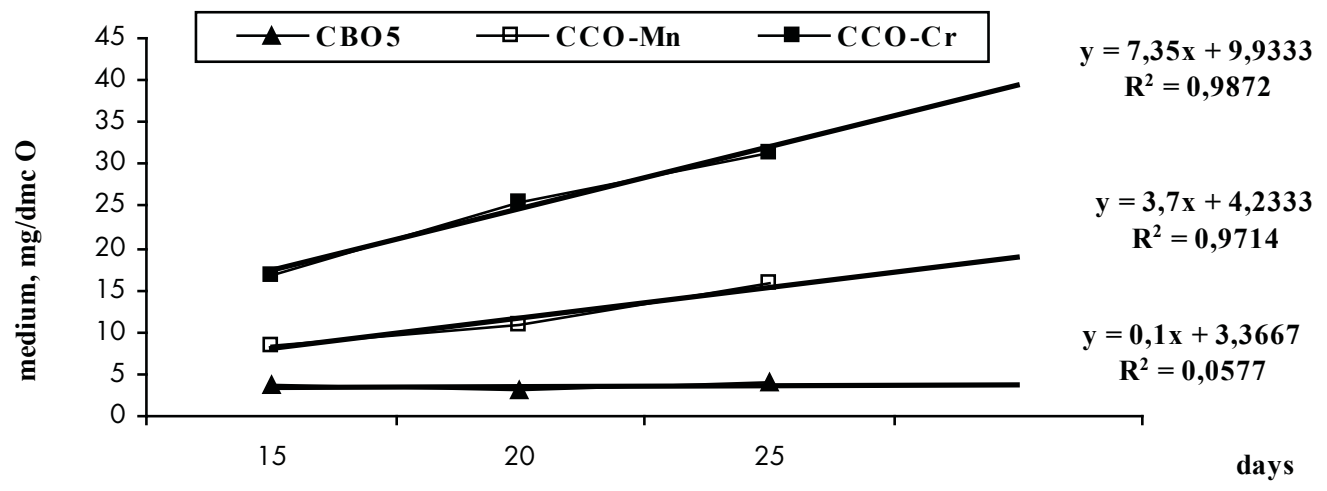

Figure 3. The correlation between the time of ammonia biochemical oxidation and BOD, COD-Mn and COD-Cr. 
It is noticed that the improvement of natural waters state (quality, self purification, nitrification) depends on the implementation of water protection measures as soon as possible.

\section{Conclusions:}

1. Effluents containing nitrogenous compounds must be treated in order to reduce the release of ammonium-N into natural waters, because this causes oxygen demand, is toxic to aquatic life, leads to eutrophication, modifying the biota and creating an ecological imbalance.

2. The concentrations of ammonium regularly exceed the MACs $\left(17,0-46,5 \mathrm{mg} / \mathrm{dm}^{3}\right.$ as N, 43,6-119 MACs, in Bac river, downstream Chisinau, maintaining their high values up to the confluence with the Nistru river).

3. $\mathrm{NH}_{4}^{+} \rightarrow \mathrm{NO}_{2}^{-}$process in modeling of small rivers lasts from 6-10 till 21-25 days in dependence of pollutants content.

4. The second stage of nitrification $\left(\mathrm{NO}_{2}^{-} \rightarrow \mathrm{NO}_{3}^{-}\right)$lsasts $15-30$ and more days.

5. The time of nitrification correlates with the content of pollutants in water: $\mathrm{BOD}_{5}, \mathrm{COD}$ and other indicators.

6. High suspended-solid content has useful implications for nitrogen removal from Raut, Lopatnic, Cubolta, Cainari, Bac river systems.

\section{References}

[1]. Waldemar Grzybowski. The significance of dissolved organic matter photodegradation as a source of ammonium in natural waters, Oceanologia 2002, no 44(3), p. 355-365.

[2]. M. Sandu, V. Ropot, V. Munteanu, P. Spătaru, V. Rusu. The role of copper ions in biochimical oxidation of Ammonia in the Nistru river Waters. "Simpozion de Chimie ecologică”. Chişinău, 1 - 4 octombrie 1995, p. 58.

[3]. Sandu Maria. Toxicity of pesticides in the presence of heavy metals on biochemical oxidation of ammonia ions. Environmentaly sound management (ESM) practices on cleaning up obsolete stockpiles of pesticides for Central European and EECCA Countries. 2005, Sofia, p. 179-181.

[4]. Sandu M., M. Negru, Gh. Duca, P. Spataru, D. Dragutan. Study on the influence of the surface-active substances on the ammonium biochemical oxidation. The Third International Conference "Ecological Chemistry 2005". Chisinau - 2005. p. 418.

[5]. Sandu Maria, Spataru P., Arapu Tatiana, Lupascu T. "Biochemical Oxidation - a Pathway for Ammonia Removal from Aquatic Systems”. NATO ARW PROGRAMME, TIMETABLE AND ORGANIZATION. "Methods and Techniques for Cleaning-up Contaminated Sites". SINAIA, 9 - 11 October, 2006. p. 313.

[6]. Spataru P., Mosanu Elena, Lupascu T., Goreacioc Tatiana, Sandu Maria. The dynamics of ammonium nitrification in the presence of aliphatic amines. The II ${ }^{\text {nd }}$ International Conference of the Chemical Society of the Republic of Moldova "Achievements and Perspectives of Modern Chemistry", Chisinau, 1-3 October, 2007, p. 101.

[7]. Mosanu E., Sandu M., Spataru P., Dragutan D. The influence of anionic and cationic surface - active substances on the process of nitrification in water. În: Mater. Simpozion Internaţional „Mediul şi Industria - SIMI 2009”, Bucureşti: 2009, p. 176.

[8]. Mosanu E., Sandu M., Spataru P., Lapteanu E. DYNAMICS OF NITRIFICATION THE PROCESS IN RIVER RAUT WATER IN CORRELATION WITH INDICATORS OF POLLUTION. În: Mater. Intern. Conference dedicated to the 50th anniversary from the foundation of the Institute of Chemistry of the Academy of Sciences of Moldova. May 26-28, 2009. Chisinau: p. 195.

[9]. Печуркин Н. С. Роль и место эксперимента на малых микробных экосистемах в количественных экологических исследованиях - В кн.: Динамика малых микробных экосистем и их звеньев. Новосибирск, 1981 , c. 3-20.

[10]. ISO 7150-1:1984. Water quality. Determination of ammonium. Part 1: Manual spectrometric method.

[11]. Лозан Р, В. Ропот, Санду М. Определение нитратов и нитритов в природных водах. Химия и технология воды.1989, т.11, N 2, стр. 120-122.

[12]. ISO 10523:1994. Water quality -- Determination of $\mathrm{pH}$.

[13]. ISO 5815-2:2003. Water quality. Determination of biochemical oxygen demand after $\mathrm{n}$ days (BODn). Part 2: Method for undiluted samples.

[14]. ISO 6060:1989. Water quality. Determination of the chemical oxygen demand.

[15]. ISO 7875-1:1996. Water quality. Determination of surfactants. Part 1: Determination of anionic surfactants by measurement of the methylene blue index (MBAS).

[16]. ISO 8467:1993. Water quality. Determination of permanganate index.

[17]. Holban V., M. Sandu. Water Pollution Sources. REPUBLIC OF MOLDOVA. STATE OF THE ENVIRONMENT REPORT in. 2006. Chsinau, 2007. p. 36-37. 
[18]. Garrido, J. M., W. A. J. Van Benthum, M. C. M. Van Loosdrecht, and J. J. Heijnen. Influence of dissolved oxygen concentration on nitrite accumulation in a biofilm airlift suspension reactor. Biotechnol. Bioeng. 1997. nr. 53, p. 168-178.

[19]. Philips, S., H. J. Laanbroek, and W. Verstraete. Origin, causes and effects of increased nitrite concentrations in aquatic environments. Rev. Environ. Sci. Biotechnol. 2002. nr. 1, p. 115-141.

[20]. Wyffels, S., P. Boeckx, K. Pynaert, W. Verstraete, and O. Van Cleemput. Sustained nitrite accumulation in a membrane-assisted bioreactor (MBR) for the treatment of ammonium-rich wastewater. J. Chem. Technol. Biotechnol. 2003. nr. 78, p. 412-419.

[21]. Xia X. H, Yang Z. F., Huang G. H., Zhang X. Q., Yu H., Rong X. Nitrification in natural waters with high suspended-solid content-a study for the Yellow River. Chemosphere, 2004, vol. 57, nr. 8, p. 1017-1029. 